\title{
Association between VDR Gene Polymorphisms and Melanoma Susceptibility in a Colombian Population
}

\author{
Andrés Felipe Aristizábal-Pachón ${ }^{1 *}$, Yeimy González-Giraldo ${ }^{1}$, Angela Yazmin \\ García $^{1}$, Dalia Xiomara Suarez ${ }^{2}$, Angela Rodríguez ${ }^{3}$, Janneth Gonzalez-Santos ${ }^{1}$
}

\begin{abstract}
Background: The vitamin D receptor (VDR) is responsible for mediating the effects of vitamin $\mathrm{D}$ through regulation of other gene transcriptions. There are several polymorphisms that alter the gene expression or the function of this protein. We aimed to analyze the association between two SNPs of VDR gene and melanoma cancer in Colombian patients. Methods: We included 120 healthy individual as controls and 120 melanoma cancer patients as cases . Patients in both groups were matched in terms of gender and age. The genotyping of rs731236 and rs2228570 polymorphisms was performed using PCR-RFLP. The SNPStats program was used to carry out the statistical analysis through a logistic regression model. Results: Under dominant model, we found that rs 2228570 polymorphism was associated with melanoma cancer risk (C/C vs C/T-T/T, OR: 5.10, 95\% CI: 2.85-9.14), whereas rs 731236 polymorphism was associated with a protective effect against this cancer (T/T vs T/C, OR: $0.27,95 \%$ CI: $0.14-0.53$ ). Conclusion: Our results suggested that both polymorphisms were involved in the development of melanoma cancer, increasing or decreasing this risk.
\end{abstract}

Keywords: Cancer- Fok1 and Taq1 genes- PCR-RFLPs- rs2228570- rs731236

Asian Pac J Cancer Prev, 23 (1), 79-85

\section{Introduction}

Melanoma is a type of skin cancer consisting of fast-growing melanocyte cells. Although melanoma is less common than other types of non-melanoma tumors, such as basal cell carcinoma (BCC) and squamous cell carcinoma (SCC), this type of malignity is more aggressive. In other words, melanoma spreads to other organs rapidly (Abbas et al., 2014). According to GLOBOCAN 2020 statistics, the worldwide incidence of melanoma was 239,758 cases, and its mortality was about 35,563. In Colombia, its incidence was 1,323 people and its mortality was 317 (Sung et al., 2021). The principal risk factors associated with melanoma development the risk of developing this pathology are exposure to ultraviolet radiation from sunshine and genetic alterations (Rastrelli et al., 2014; Kozovska et al., 2016). Several studies found an association between the risk of melanoma development and different genes, and such as CDKN2A, CDK4, BAP1, POT1, and TERT (Hayward, 2003; Read et al., 2016; Ribero et al., 2016; Nassar and Tan, 2020).

Mutations and polymorphisms in the vitamin D receptor gene (VDR) were highly correlated with melanoma and other types of cancer. VDR is a transcription factor that regulates the expression of several genes through interaction with a region in some genes named vitamin D responsive element (VDRE) (Shaffer and Gewirth, 2004; Qin and Wang, 2019). VDR regulates different targets involved in many different processes within the cells. Cellular proliferation and angiogenesis processes are inhibited, while apoptosis and cell differentiation are promoted by VDR. Different studies showed the key role of VDR in cancer development, including melanoma (Dou et al., 2016; Slominski et al., 2017; de La Puente-Yague et al., 2018; Trump and Aragon-Ching, 2018; Wu et al., 2019). It was demonstrated that polymorphisms in this gene decreased the protein functionality and its anticarcinogenic properties (Rai et al., 2017; Birke et al., 2020; Matini et al., 2020). Among the polymorphisms of VDR gene, Fok1, Bsm1, Taq1, Apa1, and Cdx2 are more frequent. These variants lead to instability of its mRNA and induce other isoforms or conformational changes in the structure of the protein (Uitterlinden et al., 2004).

In this investigation, we evaluated Fok1 (rs2228570) and Taq1 (rs731236) polymorphisms using polymerase chain reaction-restriction fragment length polymorphism (PCR-RFLP) method. The FokI polymorphism is a T/C transition (ATG to ACG), creating an alternative start site. There are two potential translation initiation sites in the exon 2 codon, generating two isoforms of different size

${ }^{1}$ Department of Nutrition and Biochemistry, Faculty of Sciences, Pontificia Universidad Javeriana, Bogotá DC, Colombia. ${ }^{2}$ University of Cundinamarca, Colombia. ${ }^{3}$ Pedagogical and Technological University of Colombia. *For Correspondence: andres_aristizabal@javeriana.edu.co 
(Cieslinska et al., 2018).

Taq 1 polymorphism is a $\mathrm{T} / \mathrm{C}$ nucleotide substitution (ATT to ATC), which leads to a synonymous change at codon of the exon 9 (Cieslinska et al., 2018; Seleit et al., 2020).

These polymorphisms have been evaluated in different types of cancers, such as breast, prostate, skin, and colorectal cancers. For rs 2228570 polymorphism, the $\mathrm{f}$ allele generates an isoform of VDR less active and effective. Previous investigations suggested that $\mathrm{ff}(\mathrm{C} / \mathrm{C})$ genotype was associated with increased risk of cancer compared with FF genotype in Caucasian population (Gandini et al., 2009; Raimondi et al., 2009; Tang et al., 2009; Zhao et al., 2014). The Taq 1 (rs731236 polymorphism) TT genotype was associated with increased risk of prostate cancer (Taylor et al., 1996). Another study reported that $\mathrm{T} / \mathrm{T}$ was associated with the risk of developing lymph node metastasis in breast cancer (Curran et al., 1999). Moreover, the $\mathrm{tt} / \mathrm{ff}$ genotypes in VDR gene were correlated with a higher risk of triggering melanoma cancer in European people (Hutchinson et al., 2000; Zeljic et al., 2014). To the best of our knowledge, there is no study investigating the relation between these SNPs in VDR gene and melanoma in Latin America population, and specifically in Colombian people. Therefore, this study was performed to analyze the association between two SNPs (rs731236 and rs2228570 polymorphisms) in VDR gene and risk of developing melanoma in Colombian population.

\section{Materials and Methods}

\section{Participants}

Here, we performed a case-control study to analyze the association between two polymorphisms in the VDR gene and melanoma cancer risk. In total, 240 participants were included in this study, 120 were patients with melanoma cancer (case group) and 120 were individuals with no history of cancer (control group). The case group were clinically and histologically diagnosed according to the classification proposed by the American Joint Committee on Cancer. The control group was healthy voluntaries matched to melanoma patients by age and other risk factors. Participants in both groups were recruited at the National Cancer Institute (INC) and Mederi hospital in Bogotá, Colombia. A blood sample was collected from all the participants.

\section{Ethics statement}

This study was performed following the recommendations of the declaration of Helsinki and the national normativity (Ministerio de Salud, Resolución $\mathrm{N}^{\circ} 008430$ de 1993), and it was approved by the Ethic committees at Applied and Environmental Sciences University in Bogotá, Colombia. All the participants provided written informed consent.

\section{DNA extraction}

First, $5 \mathrm{~mL}$ to $10 \mathrm{~mL}$ of peripheral blood was drawn from each participant and kept in EDTA containing vacutainers. The whole blood was mixed with Histopaque ${ }^{\circledR}$ (Sigma
Aldrich, San Luis, USA) and centrifuged at $1000 \mathrm{~g}$ for 30 $\min$ at $20^{\circ} \mathrm{C}$. The buffy coat with the peripheral blood mononuclear cells (PBMCs) was collected, and then genomic DNA was isolated by salting out method (Shaik et al., 2016). Next, DNA integrity was assessed using the agarose gel electrophoresis, and quantification was performed through Nanodrop 2000 (Thermo Scientific, Waltham, MA, USA).

\section{Genotyping}

A PCR followed by restriction fragment length polymorphism (RFLP) technique were employed to genotype rs2228570 and rs731236 polymorphisms in VDR gene. The PCR conditions were as following: $100 \mathrm{ng}$ of DNA, primers ( $0.15 \mathrm{pmol})$, dNTP's $(0.2 \mathrm{mM}), \mathrm{MgCl}_{2}$ $(1.2 \mathrm{mM}), 1 \mathrm{U}$ Taq polymerase (Invitrogen, Carlsbad, CA, EUA). The primer sequences were forward 5'-CTG GCA CTG ACT CTG GCT CT-3' and reverse 5'-TGC TTC TCC CTC CCT TT-3' for rs2228570 polymorphism; forward 5'-CAG AGC ATG GAC AGG GAG CAA G-3' and reverse 5'-CGG CAG CGG ATG TAG GTC TGC AG-3' for rs731236 polymorphism, which was based on a previous study (Halsall et al., 2004). PCR program consisted of a cycle at $94^{\circ} \mathrm{C}$ for $3 \mathrm{~min}, 30$ cycles at $94^{\circ} \mathrm{C}$ for $30 \mathrm{sec}$, annealing at $60^{\circ} \mathrm{C}$ for rs 2228570 polymorphism and $62^{\circ} \mathrm{C}$ for rs 731236 polymorphism during $30 \mathrm{sec}, 72^{\circ} \mathrm{C}$ for $30 \mathrm{sec}$; the last step was at $72^{\circ} \mathrm{C}$ for $5 \mathrm{~min}$. The PCR products were submitted to enzymatic digestion for 12 hours at $37^{\circ} \mathrm{C}$ using the Fok I and Taq I enzymes (Thermo Scientific, Waltham, MA, USA). The products of digestion were analyzed using agarose (3\%) gel electrophoresis stained with EZ-vision ${ }^{\circledR}$ (Amresco, Solon, OH, USA).

\section{Statistical analyses}

In this study, the observed genotypes were computed and tested for Hardy-Weinberg equilibrium using Pearson goodness-of-fit chi-square test. We performed a logistic regression to detect the association between SNPs and melanoma using the SNPStats program (Sole et al., 2006). The chi-square test $\left(\mathrm{X}^{2}\right)$ was used to detect any possible differences between the groups in the GraphPad Prism 8 program. $\mathrm{P}$ value $<0.05$ was considered significant and all statistical tests were 2 -sided.

\section{Results}

\section{Descriptive analysis}

A total of 240 participants were included in this study. Among these 240 participants, 120 were patients with melanoma (case group) and 120 were healthy subjects (control group). The participants' age average was 59.93 \pm 14.9 in the case group and $59.28 \pm 13.9$ in the control group. We found similar gender distribution in both groups. In controls, $51 \%$ were female and $49 \%$ were male. In case group, $55 \%$ were female and $45 \%$ were male. No significant differences were observed for these variables between case and control groups (Table 1).

In this study, we collected additional information on risk, such as hair color, eye color, skin color and type, tanning ability, sunblock use, cancer history in their family, from both groups. The chi-squared test findings revealed 
Table 1. Descriptive Statistics of the Analyzed Samples (120 Cases and 120 Controls).

\begin{tabular}{|c|c|c|c|}
\hline Variable & Cases $(\%)$ & Controls $(\%)$ & $\mathrm{p}$ \\
\hline Age & 59.93 & 59.28 & $0.727^{\mathrm{a}}$ \\
\hline \multicolumn{4}{|l|}{ Gender } \\
\hline Male & $54(45 \%)$ & $59(49 \%)$ & 0.051 \\
\hline Female & $66(55 \%)$ & $61(51 \%)$ & \\
\hline \multicolumn{4}{|l|}{ Hair Color } \\
\hline Black or Brown & $106(88 \%)$ & $106(88 \%)$ & 1 \\
\hline Blond(e) or red & $14(12 \%)$ & $14(12 \%)$ & \\
\hline \multicolumn{4}{|l|}{ Eye Color } \\
\hline Blue & $14(12 \%)$ & $12(10 \%)$ & 0.678 \\
\hline Other & $106(88 \%)$ & $108(90 \%)$ & \\
\hline \multicolumn{4}{|l|}{ Skin Color } \\
\hline Black or brown & $64(53 \%)$ & $72(60 \%)$ & 0.298 \\
\hline Fair & $56(47 \%)$ & $48(40 \%)$ & \\
\hline \multicolumn{4}{|l|}{ Tanning ability } \\
\hline Good & $42(35 \%)$ & $44(37 \%)$ & 0.788 \\
\hline Moderate or poor & $78(65 \%)$ & $76(63 \%)$ & \\
\hline \multicolumn{4}{|l|}{ Cancer History } \\
\hline No & $62(52 \%)$ & $70(58 \%)$ & 0.299 \\
\hline Yes & $58(48 \%)$ & $50(42 \%$ & \\
\hline \multicolumn{4}{|l|}{ Sunblock use +} \\
\hline Frequently & $16(24.2 \%)$ & $18(18.7 \%)$ & \\
\hline Rarely & $26(39.4 \%)$ & $22(22.9 \%)$ & $0.019 *$ \\
\hline Never & $24(36.4 \%)$ & $56(58.3 \%)$ & \\
\hline \multicolumn{4}{|l|}{ Sun exposition } \\
\hline Job & $40(33 \%)$ & $34(28 \%)$ & 0.402 \\
\hline Recreation & $80(67 \%)$ & $86(72 \%)$ & \\
\hline \multicolumn{4}{|l|}{ Skin type } \\
\hline Type I & $34(30 \%)$ & $30(27 \%)$ & \\
\hline Type II & $44(39 \%)$ & $46(41 \%)$ & 0.511 \\
\hline Type III & $20(18 \%)$ & $14(12 \%)$ & \\
\hline Type IV & $16(14 \%)$ & $22(20 \%)$ & \\
\hline
\end{tabular}

P-values were calculated by Chi-square test; a, Student's t-test; * Statistically significance; + For this variable, there were missing data for 54 cases and 24 controls.

no significant difference for these variables between cases and controls (Table 1), except for sunblock use. The most common cancers in the patients' family were breast, cervix, gastric, and skin cancers (data not shown ).

Clinicopathological characteristics of melanoma patients

The following clinicopathological characteristics of melanoma patients were collected: stage, Breslow depth, Clark level, melanoma type, and metastasis status (Table 2). Most of the patients were at stage I $(35 \%)$. The frequency of tumor thickness (Breslow depth) was as follows: 0-1 mm 26 (22\%); 1,1-2,0mm 21 (18\%); 2,1-4,0mm 38 (32\%); > 4,1 mm 35 (29\%). About $32 \%$ of patients were classified as Clark level V. The most common type of melanoma was acral lentiginous melanoma (59\%), followed by nodular melanoma (22\%), lentigo maligna melanoma (9\%), melanoma in situ (7\%),
Table 2. Clinicopathological Characteristics of the Melanoma Cancer Patients

\begin{tabular}{|c|c|}
\hline Characteristic & $\mathrm{n}(\%)$ \\
\hline \multicolumn{2}{|l|}{ Stage } \\
\hline I & $35(29 \%)$ \\
\hline IB & $4(3 \%)$ \\
\hline IIA & $23(19 \%)$ \\
\hline IIB & $10(8 \%)$ \\
\hline IIC & $4(3 \%)$ \\
\hline IIIA & $4(3 \%)$ \\
\hline IIIB & $24(20 \%)$ \\
\hline IIIC & $1(1 \%)$ \\
\hline IV & $15(12 \%)$ \\
\hline \multicolumn{2}{|l|}{ Breslow } \\
\hline $0-1 \mathrm{~mm}$ & $26(22 \%)$ \\
\hline $1.1-2.0 \mathrm{~mm}$ & $21(18 \%)$ \\
\hline $2.1-4.0 \mathrm{~mm}$ & $38(32 \%)$ \\
\hline$>4.1 \mathrm{~mm}$ & $35(29 \%)$ \\
\hline \multicolumn{2}{|l|}{ Clark } \\
\hline I & $2(2 \%)$ \\
\hline II & $23(19 \%)$ \\
\hline III & $30(25 \%)$ \\
\hline IV & $27(22 \%)$ \\
\hline $\mathrm{V}$ & $38(32 \%)$ \\
\hline \multicolumn{2}{|l|}{ Melanoma type } \\
\hline Lentigo maligna melanoma & $11(9 \%)$ \\
\hline Acral lentiginous melanoma & $71(59 \%)$ \\
\hline Superficial spreading melanoma & $4(3 \%)$ \\
\hline Melanoma in situ & $8(7 \%)$ \\
\hline Nodular melanoma & $26(22 \%)$ \\
\hline \multicolumn{2}{|l|}{ Metastasis } \\
\hline Yes & $15(12.5 \%)$ \\
\hline No & $105(87.5 \%)$ \\
\hline
\end{tabular}

and superficial spreading melanoma (3\%). Only 15 patients had metastasis. All data on patients' clinicopathological characteristics are presented in Table 2.

\section{Allelic and genotypic frequencies}

In the case group, the frequency for alleles $\mathrm{T}$ and $\mathrm{C}$ of rs731236 SNP were 0.89 and 0.11 , respectively. The Hardy Weinberg Equilibrium had a P value of 0.089 . In the case group, the allelic frequencies were $\mathrm{T}=0.94$ and $\mathrm{C}=0.06$, while $\mathrm{T}=0.84$ and $\mathrm{C}=0.16$ in the control group. Only two genotypes were found in these analyzed samples, namely $\mathrm{T} / \mathrm{T}$ and $\mathrm{T} / \mathrm{C}$. The genotypic frequency of $\mathrm{T} / \mathrm{T}$ was 0.78 and of $\mathrm{T} / \mathrm{C}$ was 0.22 . The genotypic frequency of $\mathrm{T} / \mathrm{T}$ was 0.88 and of $\mathrm{T} / \mathrm{C}$ was 0.12 in the case group, while it was 0.68 for $\mathrm{T} / \mathrm{T}$ and 0.32 for $\mathrm{T} / \mathrm{C}$ in the control group (Table 3 ). The allele $\mathrm{C}$ from rs 2228570 polymorphism was the most frequent allele in the total sample (0.63). The frequency of minor allele was 0.37 for allele $\mathrm{A}$. We found no significant difference from Hardy Weinberg equilibrium test for rs2228570 polymorphism (P: 0.072) in all samples. The genotypic frequencies for rs 2228570 
Table 3. Allelic and Genotypic Frequencies of rs 731236 and rs2228570 Polymorphisms in Cases and Controls

\begin{tabular}{|c|c|c|c|c|}
\hline & All subjects/ proportion & HWE (P-value) & Cases/ proportion & Controls/ proportion \\
\hline \multicolumn{5}{|c|}{$r s 731236$} \\
\hline \multicolumn{5}{|c|}{ Allelic frequencies } \\
\hline $\mathrm{T}$ & $427 / 0.89$ & & $226 / 0.94$ & $201 / 0.84$ \\
\hline $\mathrm{C}$ & $53 / 0.11$ & 0.089 & $14 / 0.06$ & $39 / 0.16$ \\
\hline \multicolumn{5}{|c|}{ Genotypic frequencies } \\
\hline $\mathrm{T} / \mathrm{T}$ & $187 / 0.78$ & & $106 / 0.88$ & $81 / 0.68$ \\
\hline $\mathrm{T} / \mathrm{C}$ & $53 / 0.22$ & & $14 / 0.12$ & $39 / 0.32$ \\
\hline \multicolumn{5}{|c|}{$r s 2228570$} \\
\hline \multicolumn{5}{|c|}{ Allelic frequencies } \\
\hline $\mathrm{C}$ & $302 / 0.63$ & 0.072 & $132 / 0.55$ & $170 / 0.71$ \\
\hline $\mathrm{T}$ & $178 / 0.37$ & & $108 / 0.45$ & $70 / 0.29$ \\
\hline \multicolumn{5}{|c|}{ Genotypic frequencies } \\
\hline $\mathrm{C} / \mathrm{C}$ & $88 / 0.37$ & & $23 / 0.19$ & $65 / 0.54$ \\
\hline $\mathrm{C} / \mathrm{T}$ & $126 / 0.52$ & & $86 / 0.72$ & $40 / 0.33$ \\
\hline $\mathrm{T} / \mathrm{T}$ & $26 / 0.11$ & & $11 / 0.09$ & $15 / 0.12$ \\
\hline
\end{tabular}

HWE, Hardy Weinberg Equilibrium; P-values were calculated by Chi-square test

polymorphism were $\mathrm{C} / \mathrm{C}(0.37), \mathrm{C} / \mathrm{T}(0.52)$, and $\mathrm{T} / \mathrm{T}(0.11)$ for all the patients included in this study (Table 3$)$.

Association between rs731236 and rs 2228570 polymorphisms and melanoma risk

We analyzed the association between rs731236 and rs2228570 polymorphisms and melanoma cancer. For rs2228570 polymorphism, several genetic models were assessed by means of a logistic regression test. This analysis was not performed for rs 731236 polymorphism since only two genotypes were identified in our samples. We observed a significant association between rs 2228570 polymorphism and melanoma cancer under codominant model $(\mathrm{OR}=6.3 ; 95 \%$ Confidence interval=3.41-11.62) and dominant model $(\mathrm{OR}=5.10 ; 95 \%$ confidence interval (2.85-9.14)). The frequency of $\mathrm{C} / \mathrm{T}-\mathrm{T} / \mathrm{T}$ genotypes was greater in cases in comparison to controls, suggesting that this variation increases the risk of melanoma cancer 5.1 times. We also observed a significant association between rs731236 polymorphism and melanoma cancer $(\mathrm{OR}=0.27 ; 95 \%$ confidence interval $(0.14-0.53)$, $\mathrm{p}$ value of 1e-04). However, for this SNP, the T/C genotype was more frequent in controls, suggesting that this polymorphism was 3.7 times more protective for melanoma cancer (Table 4).

Additionally, we evaluated the association between rs731236 and rs2228570 polymorphisms and the clinicopathological characteristics of the melanoma patients. For this purpose, we first grouped the variables as the following: Stage A (I, IB, IIA), Stage B (IIB, IIC, IIIA, IIIB, IIIC, IV), Breslow A $(\leq 2 \mathrm{~mm})$ and Breslow B (> $2 \mathrm{~mm}$ ), and Clark A (I, II, III) and Clark B (IV and $\mathrm{V})$. We only observed a significant difference for Clark variable and the rs2228570 polymorphism $(\mathrm{OR}=0.35$,

Table 4. Association between rs731236 and rs2228570 Polymorphisms and Melanoma Cancer (Adjusted by Age and Gender)

\begin{tabular}{|c|c|c|c|c|c|}
\hline Model & Genotype & Cases & Controls & OR $(95 \% \mathrm{CI})$ & $\mathrm{p}$ \\
\hline \multicolumn{6}{|l|}{$r s 731236$} \\
\hline & $\mathrm{T} / \mathrm{T}$ & $106(88.3 \%)$ & $81(67.5 \%)$ & 1 & \\
\hline--- & $\mathrm{T} / \mathrm{C}$ & $14(11.7 \%)$ & $39(32.5 \%)$ & $0.27(0.14-0.53)$ & 0.0001 \\
\hline \multicolumn{6}{|l|}{$r s 2228570$} \\
\hline \multirow[t]{3}{*}{ Codominant } & $\mathrm{C} / \mathrm{C}$ & $23(19.2 \%)$ & $65(54.2 \%)$ & 1 & \\
\hline & $\mathrm{C} / \mathrm{T}$ & $86(71.7 \%)$ & $40(33.3 \%)$ & $6.3(3.41-11.62)$ & $<0.0001$ \\
\hline & $\mathrm{T} / \mathrm{T}$ & $11(9.2 \%)$ & $15(12.5 \%)$ & $2.06(0.82-5.14)$ & 0.117 \\
\hline \multirow[t]{2}{*}{ Dominant } & $\mathrm{C} / \mathrm{C}$ & $23(19.2 \%)$ & $65(54.2 \%)$ & 1 & \\
\hline & $\mathrm{T} / \mathrm{C}-\mathrm{T} / \mathrm{T}$ & $97(80.8 \%)$ & $55(45.8 \%)$ & $5.10(2.85-9.14)$ & $<0.0001$ \\
\hline \multirow[t]{2}{*}{ Recessive } & $\mathrm{C} / \mathrm{C}-\mathrm{T} / \mathrm{C}$ & $109(90.8 \%)$ & $105(87.5 \%)$ & 1 & \\
\hline & $\mathrm{T} / \mathrm{T}$ & $11(9.2 \%)$ & $15(12.5 \%)$ & $0.70(0.30-1.59)$ & 0.392 \\
\hline \multirow[t]{2}{*}{ Overdominant } & $\mathrm{C} / \mathrm{C}-\mathrm{T} / \mathrm{T}$ & $34(28.3 \%)$ & $80(66.7 \%)$ & 1 & \\
\hline & $\mathrm{T} / \mathrm{C}$ & $86(71.7 \%)$ & $40(33.3 \%)$ & $5.26(3.01-9.18)$ & $<0.0001$ \\
\hline
\end{tabular}

P-value was calculated by Chi-Square test; $\mathrm{p}<0.05$ was considered significant and are depicted in bold 
Table 5. Association between rs731236 and rs2228570 Polymorphisms of VDR Gene and Clinicopathological Characteristics of Melanoma Cancer Patients

\begin{tabular}{|c|c|c|c|c|c|c|c|c|c|c|}
\hline & \multicolumn{4}{|c|}{ rs 731236} & \multicolumn{6}{|c|}{$r s 2228570$} \\
\hline & TT $(\%)$ & TC $(\%)$ & OR $(95 \% \mathrm{CI})$ & $\mathrm{p}$ & CC $(\%)$ & $\mathrm{TC}(\%)$ & TT $(\%)$ & $\mathrm{TC}+\mathrm{TT}(\%)$ & †OR $(95 \% \mathrm{CI})$ & $\mathrm{p}$ \\
\hline \multicolumn{11}{|l|}{ Stage } \\
\hline I - IIA & $53(85.5)$ & $9(14.5)$ & $0.56(0.17-1.77)$ & 0.319 & $11(17.7)$ & $45(72.6)$ & $6(9.7)$ & $51(82.3)$ & $0.83(0.33-2.05)$ & 0.682 \\
\hline IIB - IV & $53(91.4)$ & $5(8.6)$ & & & $12(20.7)$ & $41(70.7)$ & $5(8.6)$ & $46(79.3)$ & & \\
\hline \multicolumn{11}{|l|}{ Breslow } \\
\hline$\leq 2 \mathrm{~mm}$ & $43(91.5)$ & $4(8.5)$ & $1.71(0.50-5.80)$ & 0.391 & $9(19.1)$ & $32(68.1)$ & $6(12.8)$ & $38(80.9)$ & $0.99(0.39-2.53)$ & 0.997 \\
\hline$>2 \mathrm{~mm}$ & $63(86.3)$ & $10(13.7)$ & & & $14(19.2)$ & $54(74)$ & $5(6.8)$ & $59(80.8)$ & & \\
\hline \multicolumn{11}{|l|}{ Clark } \\
\hline $\mathrm{I}+\mathrm{II}+\mathrm{III}$ & $49(89.1)$ & $6(10.9)$ & $1.15(0.37-3.53)$ & 0.238 & $10(18.2)$ & $41(74.5)$ & $4(7.3)$ & $45(81.8)$ & $0.35(0.13-0.95)$ & 0.031 \\
\hline $\mathrm{IV}+\mathrm{V}$ & $57(87.7)$ & $8(12.3)$ & & & $13(20.0)$ & $45(69.2)$ & $7(10.8)$ & $52(80.0)$ & & \\
\hline \multicolumn{11}{|l|}{ Metastasis } \\
\hline Negative & $93(88.6)$ & $12(11.4)$ & $1.19(0.24-5.94)$ & 0.83 & $18(17.1)$ & $78(74.3)$ & $9(8.6)$ & $87(82.9)$ & $0.41(0.13-1.36)$ & 0.145 \\
\hline Positive & $13(86.7)$ & $2(13.3)$ & & & $5(33.3)$ & $8(53.3)$ & $2(13.3)$ & $10(66.7)$ & & \\
\hline
\end{tabular}

Logistic regression analysis was adjusted for age and gender; OR, Odds Ratio; CI, Confidence Interval; $\dagger$, dominant inheritance model; $\mathrm{p}<0.05$ was considered significant and are depicted in bold.

95\% confidence interval (0.13-0.95), $\mathrm{p}$-value of 0.031$)$. $\mathrm{T} / \mathrm{C}-\mathrm{T} / \mathrm{T}$ genotypes were more frequent in patients with a Clark classification of I, II, III in comparison to those with that of IV and V.

\section{Discussion}

Cancer affects many people in the worldwide. The study of the genetic basis of this disease continues to be of great importance. Numerous gene variations are associated with the risk or the protection for this pathology (Aristizabal-Pachon et al., 2015a; Aristizabal-Pachon et al., 2015b; Aristizabal-Pachon and Takahashi, 2016; Aristizabal-Pachon and Castillo, 2017; Rangel et al., 2020), including VDR gene (Birke et al., 2020). VDR has several SNPs, which may affect the amino acid sequence of the protein. Some variations affect the gene expression and consequently alter the RNA stability, such as rs731236. However, other SNPs trigger alterations on protein structure like rs2228570 polymorphism (Jakubowska-Pietkiewicz et al., 2012). In the current study, for the first time, we studied these polymorphisms of VDR gene in a Colombian sample and found significant associations between these polymorphisms and the risk of or protection against melanoma cancer.

Here, we observed that carriers of T/C-T/T genotypes induce more risk to develop melanoma skin cancer in comparison to CC carriers of rs2228570 polymorphism. $\mathrm{T}$ allele had minor frequency in our study (0.37), which is commonly denoted as $\mathrm{f}$. This variation induces a less effective protein (Whitfield et al., 2001), which can alter the control of expression of several genes with anticarcinogenic action (Rai et al., 2017). This can explain the higher susceptibility of developing melanoma cancer in $\mathrm{T}$ allele carriers. The association observed in the present study was similar to the findings reported by a meta-analysis in 2020 (Birke et al., 2020). In the aforementioned study, the authors included 11 studies with a total of 4,506 melanoma cases and 4,409 healthy controls. They reported that carriers of the rarer allele had $22 \%$ more risk to develop a malignant melanoma. In contrast to our findings, the authors did not find any significant results for rs731236 in nine included studies (4,319 melanoma cases and 3,630 healthy controls) (Birke et al., 2020). The T/C genotype was shown to have a protective effect for melanoma cancer risk $(\mathrm{OR}=0.27$ (0.14-0.53)), which is in line with results presented by $\mathrm{Li}$ et al., (2008) in Non-Hispanic Whites in Texas. In their study, the authors found that this SNP was associated with a significantly reduced melanoma cancer risk. It should be noted that rs731236 polymorphism was also associated with a protective effect for breast cancer according to a previous study (Randerson-Moor et al., 2009).

In this study, we also analyzed the association between these polymorphisms and clinicopathological characteristics of the melanoma patients in order to find out whether they were associated with progression or with the stage of the disease or not. We only observed a significant association between rs2228570 polymorphism and Clark level (Table 5), which can provide information about the invasion level (Susok et al., 2021). Although the T/T-T/C genotypes were associated with an increased risk for developing melanoma cancer, the analysis of pathological characteristics, as Clark level, revealed an association with lower levels (I, II, III), suggesting that rs2228570 polymorphism may be involved with a less degree of invasion though the role of this polymorphism in cancer invasion is not clear yet. Nevertheless, a study evaluated the expression of VDR protein in melanoma cells and detected an association with Clark levels reporting the presence of negative cytoplasmic VDR in higher levels (Randerson-Moor et al., 2009).

In conclusion, we found an association between two polymorphisms of VDR gene and melanoma cancer in a Colombian sample. However, the association was in two directions, that is rs2228570 polymorphism was associated with the risk of developing this cancer, while rs731236 polymorphism has protective effects against melanoma cancer. Further studies recruiting more samples are necessary to confirm our findings. Moreover, 
studies analyzing interactions between other genes and environmental factors could provide additional insights into the role of these polymorphisms in the development of melanoma cancer. Additionally, there is a need for genetic studies on the Latin-American population since most studies were performed in the American and European populations.

\section{Author Contribution Statement}

AFAP and JGS conceived and designed this study. AFAP, DS and AP collected samples and performed the PCR-RFLPs. AFAP and YGG performed statistical analysis and data interpretation. AFPA, YGG and AYG collected clinical data and wrote the paper. All authors read and approved the final manuscript.

\section{Acknowledgments}

The authors thank the patients and their families.

\section{Funding statement}

YGG was supported by a post-doctoral fellowship from Minciencias (Grant No. 695-2020) and a PhD fellowship from Centro de Estudios Interdisciplinarios Básicos y Aplicados CEIBA (Rodolfo Llinás Program).

\section{Conflict of Interest}

The authors declare that the research was conducted in the absence of any commercial or financial relationships that could be construed as a potential conflict of interest.

\section{References}

Abbas O, Miller DD, Bhawan J (2014). Cutaneous malignant melanoma: update on diagnostic and prognostic biomarkers. Am J Dermatopathol, 36, 363-79.

Aristizabal-Pachon AF, Carvalho TI, Carrara HH, et al (2015a). AXIN2 polymorphisms, the beta-Catenin destruction complex expression profile and breast cancer susceptibility. Asian Pac J Cancer Prev, 16, 7277-84.

Aristizabal-Pachon AF, Castillo WO (2017). Role of GSK3beta in breast cancer susceptibility. Cancer Biomark, 18, 169-75.

Aristizabal-Pachon AF, de Carvalho TI, Carrara HH, et al (2015b). Detection of human mammaglobin A mRNA in peripheral blood of breast cancer patients before treatment and association with metastasis. J Egypt Natl Canc Inst, 27, 217-22.

Aristizabal-Pachon AF, Takahashi CS (2016). [Effect of genetics, epigenetics and variations in the transcriptional expression of cadherin-E in breast cancer susceptibility]. Biomedica, 36, 593-602.

Birke M, Schope J, Wagenpfeil S, et al (2020). Association of Vitamin D receptor gene polymorphisms with melanoma risk: A Meta-analysis and Systematic Review. Anticancer Res, 40, 583-95.

Cieslinska A, Kostyra E, Fiedorowicz E, et al (2018). Single nucleotide polymorphisms in the Vitamin D receptor gene (VDR) may have an impact on acute pancreatitis (AP) development: A Prospective Study in Populations of AP Patients and Alcohol-Abuse Controls. Int J Mol Sci, 19.

Curran JE, Vaughan T, Lea RA, et al (1999). Association of A vitamin $\mathrm{D}$ receptor polymorphism with sporadic breast cancer development. Int J Cancer, 83, 723-6. de La Puente-Yague M, Cuadrado-Cenzual MA, Ciudad-Cabanas MJ, et al (2018). Vitamin D: And its role in breast cancer. Kaohsiung J Med Sci, 34, 423-7.

Dou R, Ng K, Giovannucci EL, et al (2016). Vitamin D and colorectal cancer: molecular, epidemiological and clinical evidence. Br J Nutr, 115, 1643-60.

Gandini S, Raimondi S, Gnagnarella P, et al (2009). Vitamin D and skin cancer: a meta-analysis. Eur J Cancer, 45, 634-41.

Halsall JA, Osborne JE, Potter L, et al (2004). A novel polymorphism in the $1 \mathrm{~A}$ promoter region of the vitamin $\mathrm{D}$ receptor is associated with altered susceptibilty and prognosis in malignant melanoma. Br J Cancer, 91, 765-70.

Hayward NK (2003). Genetics of melanoma predisposition. Oncogene, 22, 3053-62.

Hutchinson PE, Osborne JE, Lear JT, et al (2000). Vitamin $\mathrm{D}$ receptor polymorphisms are associated with altered prognosis in patients with malignant melanoma. Clin Cancer Res, 6, 498-504.

Jakubowska-Pietkiewicz E, Mlynarski W, Klich I, et al (2012). Vitamin D receptor gene variability as a factor influencing bone mineral density in pediatric patients. Mol Biol Rep, 39, 6243-50.

Kozovska Z, Gabrisova V, Kucerova L (2016). Malignant melanoma: diagnosis, treatment and cancer stem cells. Neoplasma, 63, 510-7.

Li C, Liu Z, Wang LE, et al (2008). Haplotype and genotypes of the VDR gene and cutaneous melanoma risk in nonHispanic whites in Texas: a case-control study. Int J Cancer, 122, 2077-84.

Matini AH, Jafarian-Dehkordi N, Bahmani B, et al (2020). Association of ApaI and TaqI polymorphisms in VDR Gene with Breast Cancer. Asian Pac J Cancer Prev, 21, 2667-72.

Nassar KW, Tan AC (2020). The mutational landscape of mucosal melanoma. Semin Cancer Biol, 61, 139-48.

Qin X, Wang X (2019). Role of vitamin D receptor in the regulation of CYP3A gene expression. Acta Pharm Sin B, 9, 1087-98.

Rai V, Abdo J, Agrawal S, et al (2017). Vitamin D receptor polymorphism and cancer: An Update. Anticancer Res, 37, 3991-4003.

Raimondi S, Johansson H, Maisonneuve P, et al (2009). Review and meta-analysis on vitamin $\mathrm{D}$ receptor polymorphisms and cancer risk. Carcinogenesis, 30, 1170-80.

Randerson-Moor JA, Taylor JC, Elliott F, et al (2009). Vitamin D receptor gene polymorphisms, serum 25-hydroxyvitamin D levels, and melanoma: UK case-control comparisons and a meta-analysis of published VDR data. Eur J Cancer, 45, 3271-81.

Rangel N, Rondon-Lagos M, Annaratone L, et al (2020). AR/ER ratio correlates with expression of proliferation markers and with distinct subset of breast tumors. Cells, $\mathbf{9}$.

Rastrelli M, Tropea S, Rossi CR, et al (2014). Melanoma: epidemiology, risk factors, pathogenesis, diagnosis and classification. In Vivo, 28, 1005-11.

Read J, Wadt KA, Hayward NK (2016). Melanoma genetics. J Med Genet, 53, 1-14.

Ribero S, Glass D, Bataille V (2016). Genetic epidemiology of melanoma. Eur J Dermatol, 26, 335-9.

Seleit I, Bakry OA, Badr E, et al (2020). Vitamin D receptor gene polymorphisms Taq-1 and Cdx-1 in female pattern hair loss. Indian J Dermatol, 65, 259-64.

Shaffer PL, Gewirth DT (2004). Vitamin D receptor-DNA interactions. Vitam Horm, 68, 257-73.

Shaik M, Shivanna DK, Kamate M, et al (2016). Single lysissalting out method of genomic DNA extraction from dried blood spots. J Clin Lab Anal, 30, 1009-12.

Slominski AT, Brozyna AA, Zmijewski MA, et al (2017). 
Vitamin D signaling and melanoma: role of vitamin D and its receptors in melanoma progression and management. Lab Invest, 97, 706-24.

Sole X, Guino E, Valls J, et al (2006). SNPStats: a web tool for the analysis of association studies. Bioinformatics, 22, 1928-9.

Sung H, Ferlay J, Siegel RL, et al (2021). Global cancer statistics 2020: GLOBOCAN estimates of incidence and mortality worldwide for 36 cancers in 185 countries. CA Cancer $J$ Clin, 2021.

Susok L, Stucker M, Bechara FG, et al (2021). Multivariate analysis of prognostic factors in patients with nodular melanoma. J Cancer Res Clin Oncol, 2021.

Tang C, Chen N, Wu M, et al (2009). Fok1 polymorphism of vitamin D receptor gene contributes to breast cancer susceptibility: a meta-analysis. Breast Cancer Res Treat, 117, 391-9.

Taylor JA, Hirvonen A, Watson M, et al (1996). Association of prostate cancer with vitamin $D$ receptor gene polymorphism. Cancer Res, 56, 4108-10.

Trump DL, Aragon-Ching JB (2018). Vitamin D in prostate cancer. Asian J Androl, 20, 244-52.

Uitterlinden AG, Fang Y, Van Meurs JB, et al (2004). Genetics and biology of vitamin D receptor polymorphisms. Gene, 338, 143-56.

Whitfield GK, Remus LS, Jurutka PW, et al (2001). Functionally relevant polymorphisms in the human nuclear vitamin D receptor gene. Mol Cell Endocrinol, 177, 145-59.

$\mathrm{Wu}$ X, Hu W, Lu L, et al (2019). Repurposing vitamin D for treatment of human malignancies via targeting tumor microenvironment. Acta Pharm Sin B, 9, 203-19.

Zeljic K, Kandolf-Sekulovic L, Supic G, et al (2014). Melanoma risk is associated with vitamin D receptor gene polymorphisms. Melanoma Res, 24, 273-9.

Zhao XZ, Yang BH, Yu GH, et al (2014). Polymorphisms in the vitamin D receptor (VDR) genes and skin cancer risk in European population: a meta-analysis. Arch Dermatol Res, 306, 545-53.

This work is licensed under a Creative Commons AttributionNon Commercial 4.0 International License. 